Check for updates

Cite this: RSC Adv., 2020, 10, 31947

\section{Full crystal structure, hydrogen bonding and spectroscopic, mechanical and thermodynamic properties of mineral uranopilite $\uparrow$}

\author{
Francisco Colmenero, (D) *a Jakub Plášil, (D) ${ }^{b}$ Vicente Timón (D) a and Jiří Čejka ${ }^{c}$
}

The determination of the full crystal structure of the uranyl sulfate mineral uranopilite, $\left(\mathrm{UO}_{2}\right)_{6}\left(\mathrm{SO}_{4}\right)$ $\mathrm{O}_{2}(\mathrm{OH})_{6} \cdot 14 \mathrm{H}_{2} \mathrm{O}$, including the positions of the hydrogen atoms within the corresponding unit cell, has not been feasible to date due to the poor quality of its X-ray diffraction pattern. In this paper, the complete crystal structure of uranopilite is established for the first time by means of first principles solid-state calculations based in density functional theory employing a large plane wave basis set and pseudopotential functions. The computed unit-cell parameters and structural data for the non-hydrogen atoms are in excellent agreement with the available experimental data. The computed X-ray diffraction pattern is also in satisfactory agreement with the experimental pattern. The infrared spectrum of uranopilite is collected from a natural crystal specimen originating in Jáchymov (Czech Republic) and computed employing density functional perturbation theory. The theoretical and experimental vibrational spectra are highly consistent. Therefore, a full assignment of the bands in the experimental infrared spectrum is performed using a normal mode analysis of the first principles vibrational results. One overtone and six combination bands are recognized in the infrared spectrum. The elasticity tensor and phonon spectra of uranopilite are computed from the optimized crystal structure and used to analyze its mechanical stability, to obtain a rich set of elastic properties and to derive its fundamental thermodynamic properties as a function of temperature. Uranopilite is shown to have a large mechanical anisotropy and to exhibit the negative Poisson's ratio and negative linear compressibility phenomena. The calculated specific heat and entropy at $298.15 \mathrm{~K}$ are 179.6 and $209.0 \mathrm{~J} \mathrm{~K}^{-1} \mathrm{~mol}^{-1}$, respectively. The computed fundamental thermodynamic functions of uranopilite are employed to obtain its thermodynamic functions of formation in terms of the elements and the thermodynamic properties of a set of chemical reactions relating uranopilite with a representative group of secondary phases of spent nuclear fuel. From the reaction thermodynamic data, the relative stability of uranopilite with respect to these secondary phases is evaluated as a function of temperature and under different hydrogen peroxide concentrations. From the results, it follows that uranopilite has a very large thermodynamic stability in the presence of hydrogen peroxide. The high stability of uranopilite under this condition justify its early crystallization in the paragenetic sequence of secondary phases occurring when uranium dioxide is exposed to sulfur-rich solutions.
Received 24th May 2020

Accepted 18th August 2020

DOI: $10.1039 / \mathrm{dOra04596a}$

rsc.li/rsc-advances environmentally important and abundant uranyl sulfate minerals. ${ }^{7-12}$ This mineral was first described in 1854 by Dauber $^{13}$ from Jáchymov (former Bohemia, as part of the Austrian empire, now Czech Republic) and by Weisbach ${ }^{\mathbf{1 4}}$ from
${ }^{a}$ Instituto de Estructura de la Materia (IEM-CSIC), C/ Serrano, 113, 28006 Madrid, Spain. E-mail: francisco.colmenero@iem.cfmac.csic.es

${ }^{b}$ Institute of Physics ASCR, v.v.i., Na Slovance 2, 182 21, Praha 8, Czech Republic

'Mineralogicko-petrologické oddělení, Národni muzeum, Cirkusová 1740, 19300 Praha 9, Czech Republic

$\uparrow$ Electronic supplementary information (ESI) available: (a) Calculated positions of the atoms within the unit cell of uranopilite. (b) Experimental and first principles methods employed in this work; (c) detailed description of the experimental and computed infrared spectra; (d) thermal decomposition curve (Fig. S.1); (e) computed density of states and frontier band functions; (f) interatomic distances; $(\mathrm{g})$ most intense reflections in the X-ray powder pattern; (h) resolution of the infrared bands into single components; (h) depictions of the vibrational motions associated to a subset of the most important infrared active normal modes (i) comparison of the experimental infrared band wavenumbers and those from the literature $(j)$ computed elastic constants; (k) calculated unit-cell volume and parameters as a function of the applied external pressures; (l) compressibility values as a function of the external pressure; (m) calculated fundamental thermodynamic functions; (n) thermodynamic properties of reaction. CCDC 1961689. For ESI and crystallographic data in CIF or other electronic format see DOI: 10.1039/d0ra04596a 
Johanngeorgenstadt (Saxony, Germany). Uranopilite is a highly hydrated mineral whose crystal structure ${ }^{2}$ has a topology which is not present in the structure of any other uranyl sulfate material. ${ }^{7-12}$ The crystal structure of uranopilite contains layers composed of hydrogen-bonded infinite chains or bands. The structure of these bands in uranopilite is one of the most complex found so far in the structure of a uranyl mineral. The determination of the hydrogen bond structure of uranopilite is a long standing problem ${ }^{2,5,6}$ whose solution has not been possible due to the complexity of its X-ray diffraction pattern and the paucity of well-developed crystals. The twinning of the uranopilite crystals leads to the existence of a large number overlapping reflections and unresolved artifacts which, together with a poor absorption correction, are the cause of highly positive difference Fourier maps in the proximity of the uranium atoms within the uranopilite chains, which hinders the determination of the hydrogen atom positions within its unit cell. ${ }^{6}$ However, this problem may be lifted by using theoretical approaches to determine the complete crystal structure of uranopilite. The first principles solid-state methodology based on Density Functional Theory (DFT) has been previously employed successfully to determine the complete crystal structures of fundamental uranyl-containing minerals such as schoepite ${ }^{15}$ metaschoepite, ${ }^{16}$ becquerelite, ${ }^{17}$ kasolite, ${ }^{18}$ uranophane- $\beta,{ }^{19}$ vandenbrandeite, ${ }^{20}$ uranosphaerite ${ }^{21}$ and bayleyite. ${ }^{22}$ The hydrogen bond network structure present in the unit cell of uranopilite is unveiled in this work.

Uranyl sulfate minerals are invariably found in uranium deposits where uraninite commonly coexists with sulfide minerals. Uranopilite is frequently found on the surface of altered uraninite or in its vicinity. ${ }^{6,8}$ In these deposits, the oxidative dissolution processes of sulfide minerals lead to the formation of sulfur rich solutions with low $\mathrm{pH}$ known as acidmine drainage. ${ }^{23-26}$ These acid solutions, generated after mining and ore processing contain high concentrations of metals and toxic elements (such as $\mathrm{U}, \mathrm{Cd}, \mathrm{Cr}, \mathrm{Pb}$ and $\mathrm{As}$ ) and drain from stockpiles of waste rock, mill tailings and open pits at or near the mine site, into surface streams, rivers and lakes leading to the deterioration of the water quality. The precipitation and dissolution of uranyl sulfate minerals are among the most important processes limiting the solubility of uranium in these deposits. The dissolution of these minerals leads to the formation of highly mobile aqueous uranyl sulfate complexes $^{27-40}$ which may be transported long distances away from the deposit and, therefore, control the migration of uranium at the large scale. ${ }^{\mathbf{4 1 - 4 4}}$ The oxidative dissolution processes of sulfide minerals and the presence of large metal water concentrations in soils with high sulfate contents can also occur in the absence of mining and may have both anthropogenic and non-anthropogenic origin. ${ }^{23,45-50}$ The presence of sulfur compounds $s^{48,49}$ and biogenic $\operatorname{processes}^{50}$ were fundamental for the genesis of many uranium ore deposits. ${ }^{51}$ The study of the precipitation/dissolution processes of uranyl sulfate minerals is also highly relevant for the performance assessment of spent nuclear fuel repositories. ${ }^{52-57}$

In order to make progress in all the fields related to the confinement of uranium containing wastes, a substantial amount of research should be made to perform large scale numerical modeling calculations to identify the main geochemical processes involved and to assess the effectiveness of the barrier systems used to prevent the long term migration of contaminants. ${ }^{\mathbf{5 8 , 5 9}}$ Numerical simulations are the only method that allows to recognize the highly multidisciplinary nature of the problem and takes in account the complex coupled interaction between geology, hydrology, mechanics, chemistry, biogeochemistry and thermodynamics for the precise geometry of the site being studied. Appropriate numerical simulations using highly developed and augmented reactive transport codes are an essential ingredient of the longterm performance assessment of nuclear waste repositories. ${ }^{28,29,60-65}$ A serious weakness in the current knowledge base is the lack of reliable temperature dependent thermodynamic information for the most important chemical species and chemical reactions involved..$^{31,66-68}$ The elaboration of a complete chemical thermodynamic database ${ }^{27,28,69,70}$ is mandatory if we desire to bring the results of such simulations in agreement with the experimental information. The stabilities and the dissolution reaction constants of a given mineral are dependent on the temperature, composition and local conditions ( $\mathrm{pH}$ and $E_{\mathrm{H}}$ ), and the knowledge of its Gibbs free energy, enthalpy, and entropy thermodynamic functions of formation, including their variation with temperature, is required for their prediction. The case of the uranyl sulfate minerals is particularly important because, saving the minerals of the zippeite group,${ }^{71,72}$ there is not thermodynamic information for the most of these environmentally important minerals even at room temperature. The need of thermodynamic data for uranyl sulfate minerals, due to its enormous relevance under acidic conditions, has been recognized in the past ${ }^{29,73}$ and has still not been addressed. The availability of accurate thermodynamic data for uranyl sulfate minerals should allow to obtain a deep knowledge about the formation processes of these minerals and of the interaction of uranium and sulfide minerals at several time scales and environmental conditions which is currently poorly understood..$^{74}$ One of the main purposes of this paper is to provide precise temperature dependent thermodynamic data for one of the most important uranyl sulfate minerals, uranopilite, ${ }^{1-6}$ and, from them, to investigate its connection with the dissolution/precipitation processes occurring when uranium dioxide is exposed to oxidizing conditions in the presence of $\mathrm{SO}_{4}{ }^{2-}$ anions. Uranopilite has very high uranium content and is the earliest uranyl sulfate mineral appearing in the paragenetic sequence of uranyl-containing minerals occurring due to the corrosion of uranium ore deposits when the ore is exposed to oxidizing low $\mathrm{pH}$ sulfur-rich solutions. It should be noticed that a closely related mineral phase, referred to as metauranopilite, is usually described as its dehydration product. However, this mineral phase, described from a single specimen by Nováček ${ }^{75,76}$ in 1935 , is dubious. ${ }^{8,77}$ Another, closely related mineral is jáchymovite, ${ }^{78}\left(\mathrm{UO}_{2}\right)_{8}\left(\mathrm{SO}_{4}\right)(\mathrm{OH})_{14} \cdot 13 \mathrm{H}_{2} \mathrm{O}$. Despite of the absence of structural data, it is clear that this mineral differs significantly from uranopilite in the $\mathrm{U}: \mathrm{S}$ ratio and total water content. 
2

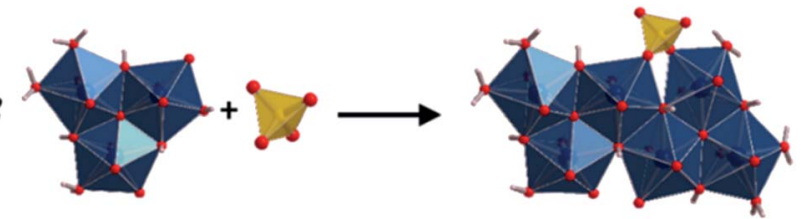

Fig. 1 Fundamental building units in the crystal structure of uranopilite: the uranyl trimer and the sulfate tetrahedron. Two uranyl trimers and a sulfate tetrahedron combine to form a basic uranyl sulfate unit

In this work, the infrared spectrum, the elasticity tensor and the phonon spectra of uranopilite were determined from the computed equilibrium crystal structure by using large-scale first-principles calculations (see the Appendix A of the ESI†). The experimental infrared spectrum of uranopilite was collected from a natural mineral specimen originating in Jáchymov (Czech Republic). The collected spectrum was found to be in excellent agreement with the theoretical spectrum and, therefore, all the infrared bands were assigned to specific vibrational atomic motions by performing a normal coordinate analysis of the theoretical vibrational results. The study of the spectral signatures of uranium containing materials is crucial in many research fields ranging from nuclear forensics to nuclear waste storage for their precise identification. ${ }^{10,79,80}$ Therefore, a detailed spectroscopic characterization is given. From the computed elasticity tensor, the mechanical stability of uranopilite crystal structure was analyzed and a rich set of relevant mechanical properties of this mineral, unknown as far as we know, were determined. The fundamental thermodynamic properties of uranopilite as a function of temperature were derived from the computed phonon spectra. As the mechanical properties, the thermodynamic parameters of uranopilite have not being measured experimentally and are reported here for the first time. The computed fundamental thermodynamic functions were then employed to obtain the thermodynamic properties of formation of uranopilite in terms of the elements and the thermodynamic properties of reaction of a series of reactions involving uranopilite and a subset of the most prominent secondary phases of spent nuclear fuel (SNF). From the temperature dependent thermodynamic reaction data, the relative thermodynamic stability of uranopilite with respect to these secondary phases of SNF were obtained as a function of temperature and under the presence of different concentrations of hydrogen peroxide $\left(\mathrm{H}_{2} \mathrm{O}_{2}\right)$.

\section{Results and discussion}

\subsection{The crystal structure of uranopilite}

The fundamental building units in uranopilite crystal structure are shown in Fig. 1. The uranium atom in uranopilite displays pentagonal bipyramidal coordination and the sulfur atom, as usual, displays tetrahedral coordination. Each uranyl pentagonal bipyramid shares two edges with other two bipyramids to form a trimer, $\left[\left(\mathrm{UO}_{2}\right)_{3} \mathrm{O}_{2}(\mathrm{OH})_{4}\left(\mathrm{H}_{2} \mathrm{O}\right)_{3}\right]^{2-}$. Two trimers and one sulfate tetrahedron, $\mathrm{SO}_{4}{ }^{2-}$, combine to form a basic uranyl sulfate unit, $\left[\left(\mathrm{UO}_{2}\right)_{6} \mathrm{O}_{4}(\mathrm{OH})_{6}\left(\mathrm{SO}_{4}\right)\left(\mathrm{H}_{2} \mathrm{O}\right)_{6}\right]^{4-}$ as represented schematically in Fig. 1 . The computed full crystal structure of uranopilite is plotted in Fig. 2 .

As shown in Fig. 2B, the uranyl sulfate units share the two free vertices of the sulfate tetrahedra to form neutral chains expanding along [100] crystallographic direction. These chains are between three and four uranyl-polyhedra wide and, therefore, are better described as bands. The different bands,

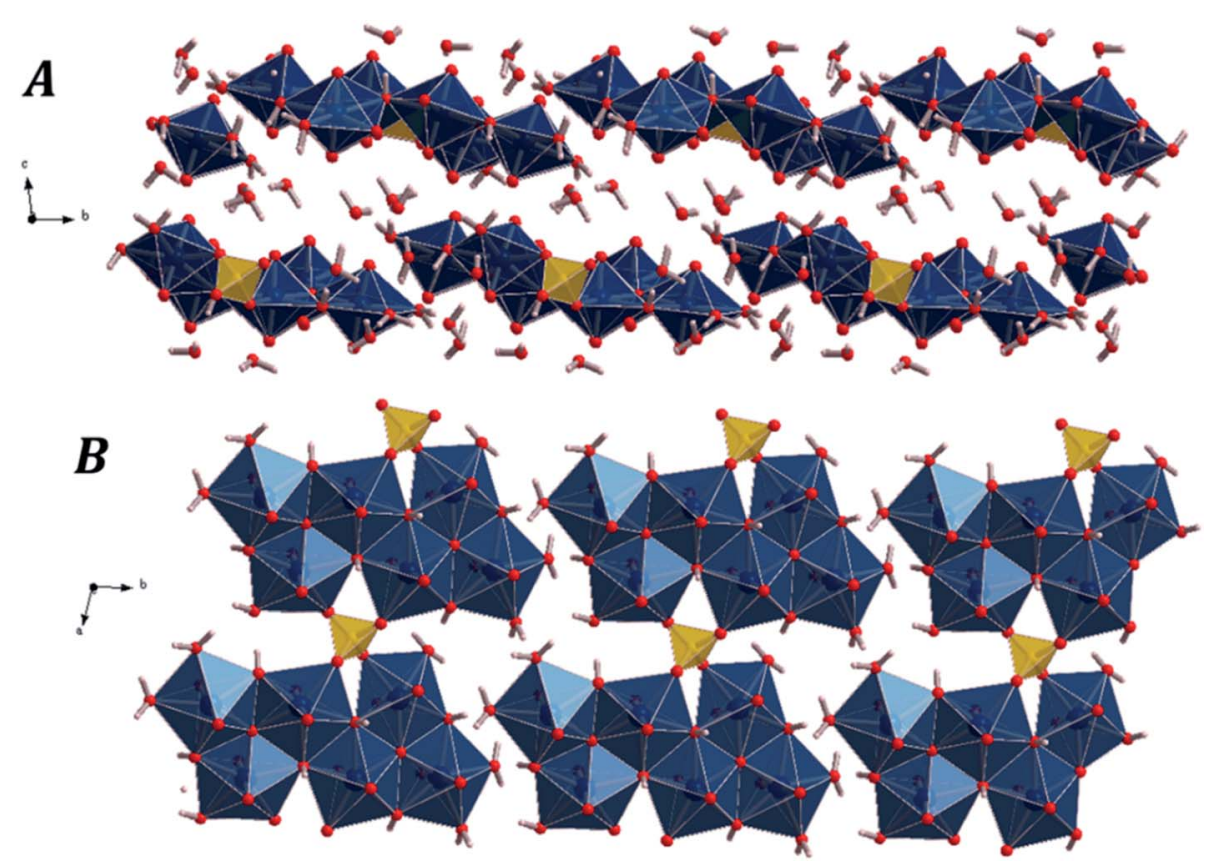

Fig. 2 The crystal structure of uranopilite: (A) view of two uranyl sulfate layers and their interlayer space from [100] direction; (B) view of a single uranyl sulfate layer from [001] direction. 
although slightly tilted, are placed around a given plane and linked by means of hydrogen bonds to form complex layers (or pseudo-layers) parallel to the (110) plane. The space between the layers is occupied by water molecules. Two uranopilite parallel layers and their interlayer space are shown in Fig. 2A. Fig. 2B displays a single layer from [001], the direction perpendicular to the layers.

The computed unit-cell parameters of uranopilite and the corresponding unit-cell volume and density are reported in Table 1. In this table, the experimental values obtained up to date are also given for comparison. The computed values using the DFT-D2 approach are in very good agreement with the experimental values. The deviation between the calculated and experimental volumes is only about $0.4 \%$ with respect to the value reported by Burns ${ }^{2}$ and $1.6 \%$ with respect to the value reported by Plášil et al. ${ }^{6}$ The inclusion of dispersion corrections improves substantially the computed crystal structure since, as can be observed in the first row of Table 1, if the uncorrected PBE functional is used, the error in the computed volume increases up to $4.8 \%$ with respect to the volume given by Burns. ${ }^{2}$

As can also be seen in Table 1 (third row), the Hubbard correction, which was used with a value of the effective Hubbard parameter $^{81}$ of $U_{\text {eff }}=4.0 \mathrm{eV}$, does not introduce significant variations of the computed crystal structure. The insignificance of the Hubbard correction may be understood from Fig. S.2 and S. 3 of the ESI $\dagger$ in which the computed electron density of states of uranopilite and the frontier band functions (the highest occupied and lowest unoccupied one-electron wavefunctions) are plotted, respectively. The DFT-D2 approach predicts correctly that uranopilite is an insulator with a band gap of $2.27 \mathrm{eV}$ (Fig. S.2†). Furthermore, the highest occupied band function is mainly composed of contributions localized in $\mathrm{p}$ orbitals of oxygen atoms and d orbitals of uranium and the lowest unoccupied wavefunction is highly localized in f orbitals of uranium atoms. Because the f orbitals in uranium are empty and separated by almost $2.3 \mathrm{eV}$ from the highest occupied band function, the Hubbard correction, improving the description of the strong correlation between electrons occupying f orbitals, is not needed. As an additional check, the infrared spectrum of uranopilite was determined using the Hubbard correction and the results were essentially the same as those reported in Sec. 2.4 obtained without the Hubbard correction. Due to the small impact of this correction for uranopilite, it was not employed to obtain its mechanical and thermodynamic properties.
There are six symmetrically independent uranium atoms (referred to as U1 to U6) and only one independent sulfur atom (S1) in the structure of uranopilite. The interatomic distances derived from the computed crystal structure are reported in Table S. 1 of the ESI $\dagger$. The experimental values of these distances reported by Burns ${ }^{2}$ are also given in Table S.1. $\dagger$ Both sets of distances are in excellent agreement. The experimental average $\mathrm{U}-\mathrm{O}$ distances for the upper and lower apical oxygen atoms in the uranyl pentagonal bipyramids are 1.81(2), 1.82(2), 1.80(2), $1.79(2), 1.76(2)$ and $1.76(2) \AA$ and the corresponding computed values $1.80,1.80,1.80,1.79,1.80$ and $1.80 \AA$, respectively. The computed values agree also very well with the mean value of $1.79 \AA$ obtained from many well-refined uranyl mineral crystal structures. ${ }^{82}$ Likewise, the experimental average U-O distances for the oxygen atoms in the equatorial positions in the uranyl bipyramids are 2.41(2), 2.39(2), 2.41(2), 2.39(2), 2.39(2) and 2.41(2) $\AA$, which can be compared with the corresponding theoretical values: $2.40,2.39,2.40,2.44,2.41$ and $2.39 \AA$, respectively. Again, these values agree well with the value of 2.37 $\AA$ obtained by Burns et $a .^{82}$ by averaging the corresponding values for a numerous set of well-refined structures involving pentagonal bipyramidal coordination on uranium atom. The theoretical and experimental average $\mathrm{S}-\mathrm{O}$ distances are the same, $1.49 \AA$ A. The computed full crystal structure of uranopilite is included in the ESI $\dagger$ in a file with CIF (Crystallographic Information File) format.

\subsection{Hydrogen bonding}

The hydrogen bonding network structure in uranopilite is very complex as expected for a highly hydrated mineral with a unit cell containing twenty-eight water molecules (fourteen per formula unit). The computed hydrogen bond parameters are reported in Table 2 . Thirty-two different hydrogen bonds were found. Six of them are associated to the hydroxyl ions and twenty-six to the interlayer water molecules.

From the positions of the non-hydrogen atoms, Burns ${ }^{2}$ suggested a possible hydrogen bond distribution in uranopilite using crystal chemical considerations. The hydrogen bond structure afforded by the first principles calculations is slightly different to the qualitative picture inferred by Burns. ${ }^{2}$ The differences can be mainly attributed to temperature effects, because the computed structure corresponds to zero temperature and the experimental one to room temperature, and to the

Table 1 Unit cell parameters of uranopilite. The theoretical and experimental values correspond to zero and room temperature, respectively

\begin{tabular}{|c|c|c|c|c|c|c|c|c|}
\hline Parameter & $a(\AA)$ & $b(\AA)$ & $c(\AA)$ & $\alpha(\mathrm{deg})$ & $\beta$ (deg) & $\gamma(\mathrm{deg})$ & Vol. $\left(\AA^{3}\right)$ & $\rho\left(\mathrm{g} \mathrm{cm}^{-3}\right)$ \\
\hline PBE & 9.0171 & 14.3018 & 14.6067 & 93.74 & 99.67 & 101.70 & 1808.69 & 3.861 \\
\hline DFT-D2 & 8.9466 & 14.1497 & 14.2549 & 94.57 & 99.16 & 101.59 & 1733.59 & 4.028 \\
\hline Exp.6 & $8.8556(9)$ & $13.9819(15)$ & $14.3070(30)$ & $96.749(12)$ & $98.754(12)$ & $99.726(9)$ & 1706.91 & 4.091 \\
\hline Exp. 2 & $8.896(2)$ & $14.029(3)$ & $14.339(3)$ & $96.610(4)$ & $98.472(4)$ & $99.802(4)$ & 1726.03 & 4.046 \\
\hline Exp.5 & $8.901(2)$ & $14.042(3)$ & $14.521(3)$ & $97.41(3)$ & $98.97(3)$ & $99.69(3)$ & 1744.58 & 4.003 \\
\hline
\end{tabular}


Table 2 Hydrogen bond parameters $(\mathrm{O} 1-\mathrm{H} \cdots \mathrm{O} 2)$ in uranopilite (distances in $\AA$ and angles in degrees)

\begin{tabular}{|c|c|c|c|}
\hline Hydrogen bond & $\mathrm{O} 1 \cdots \mathrm{O} 2$ & $\mathrm{H} \cdots \mathrm{O} 2$ & $A(\mathrm{O} 1-\mathrm{H} \cdots \mathrm{O} 2)$ \\
\hline \multicolumn{4}{|l|}{ O1(hydroxyl)-H $\cdots$ O2 } \\
\hline OH19-H19 $\cdots$ OW33 & 2.668 & 1.663 & 175.20 \\
\hline OH $20-\mathrm{H} 20 \cdots$ OW 29 & 2.788 & 1.816 & 170.17 \\
\hline $\mathrm{OH} 21-\mathrm{H} 21 \cdots \mathrm{OW} 28$ & 2.968 & 1.991 & 175.61 \\
\hline $\mathrm{OH} 22-\mathrm{H} 22 \cdots \mathrm{OW} 32$ & 2.812 & 1.822 & 172.91 \\
\hline $\mathrm{OH} 23-\mathrm{H} 23 \cdots$ OW26 & 3.030 & 2.074 & 164.47 \\
\hline $\mathrm{OH} 24-\mathrm{H} 24 \cdots$ OW30 & 2.861 & 1.884 & 171.79 \\
\hline \multicolumn{4}{|l|}{ O1(water)-H $\cdots \mathbf{O} 2$} \\
\hline OW25-H25a $\cdots$ OW31 & 2.585 & 1.622 & 158.44 \\
\hline OW25-H25b $\cdots$ OW34 & 2.664 & 1.681 & 166.97 \\
\hline OW26-H26b $\cdots$ OW31 & 2.727 & 1.745 & 166.50 \\
\hline OW26-H26a $\cdots$ OW35 & 2.738 & 1.771 & 162.33 \\
\hline OW27-H27b $\cdots$ OW25 & 2.686 & 1.694 & 171.36 \\
\hline 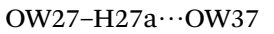 & 2.571 & 1.585 & 164.43 \\
\hline OW28-H28b $\cdots \mathrm{O} 11$ & 2.679 & 1.692 & 169.18 \\
\hline OW28-H28a $\cdots \mathrm{O} 5$ & 2.935 & 2.103 & 141.88 \\
\hline OW29-H29b $\cdots$ OW34 & 3.221 & 2.503 & 130.65 \\
\hline OW29-H29a $\cdots$ OW38 & 2.593 & 1.587 & 168.84 \\
\hline OW30-H30b $\cdots$ OW38 & 2.736 & 1.757 & 167.34 \\
\hline OW30-H30a $\cdots$ OW36 & 2.657 & 1.648 & 176.58 \\
\hline 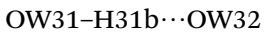 & 2.703 & 1.713 & 174.45 \\
\hline OW31-H31a $\cdots$ OH21 & 2.723 & 1.735 & 170.26 \\
\hline OW32-H32a $\cdots$ OW35 & 2.716 & 1.729 & 168.97 \\
\hline OW33-H33a $\cdots$ OW34 & 2.727 & 1.740 & 170.06 \\
\hline 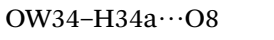 & 2.977 & 2.109 & 147.16 \\
\hline OW34-H34b $\cdots \mathrm{OH} 24$ & 2.757 & 1.766 & 171.55 \\
\hline OW35-H35b $\cdots$ OW33 & 2.659 & 1.673 & 167.39 \\
\hline OW35-H35a $\cdots \mathrm{O} 12$ & 2.913 & 2.273 & 122.43 \\
\hline OW36-H36а $\cdots \mathrm{O} 1$ & 2.771 & 1.817 & 161.70 \\
\hline OW36-H36b $\cdots$ O5 & 2.789 & 1.831 & 164.01 \\
\hline OW37-H37b $\cdots \mathrm{O} 3$ & 2.760 & 1.776 & 174.28 \\
\hline OW37-H37a $\cdots$ OW36 & 2.730 & 1.764 & 163.17 \\
\hline OW38-H38a $\cdots \mathrm{O} 10$ & 2.721 & 1.793 & 155.98 \\
\hline OW38-H38b $\cdots$ OW37 & 2.682 & 1.690 & 171.67 \\
\hline
\end{tabular}

qualitative nature of the picture inferred by Burns. ${ }^{2}$ The determination of the energy-optimized positions of the hydrogen atoms in a given crystal structure is a significant addition because it specifies the hydrogen bond structure in a precise way. Furthermore, from the theoretical point of view, it allows to determine the vibrational spectra and material properties using the first principles methodology.

\subsection{X-ray powder diffraction patterns}

The X-ray diffraction patterns of uranopilite associated to the computed and experimental ${ }^{2}$ (without the hydrogen atoms) crystal structures were determined utilizing the program REFLEX belonging to the Materials Studio package of programs. ${ }^{83}$ The patterns were determined with a X-ray radiation wavelength of $\lambda=1.540598 \AA$ ( $\mathrm{CuK}_{\alpha}$ radiation). The patterns obtained are compared in Fig. 3 and as can be observed they agree faithfully. Table S.2 of the ESI. $\dagger$ provides an exhaustive comparison of the computed and experimental positions and intensities of the nineteen more intense reflections. The X-ray powder pattern of uranopilite is quite complex

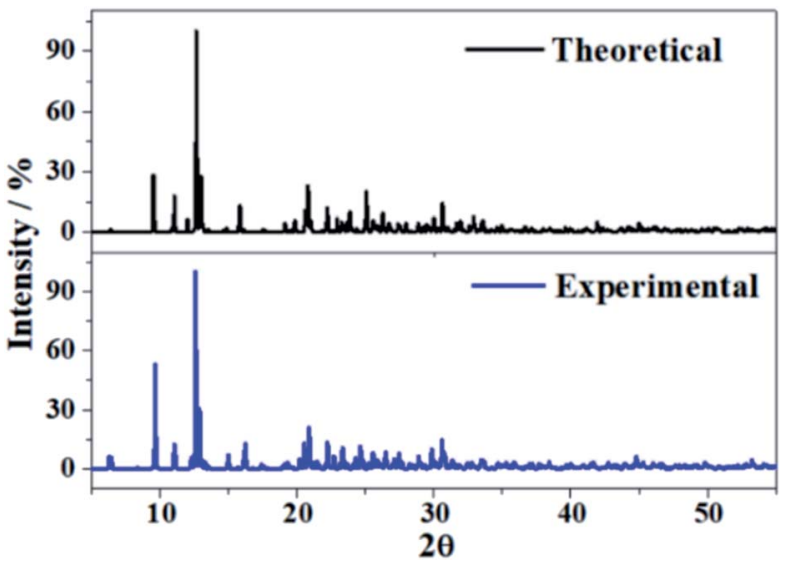

Fig. 3 X-ray powder diffraction patterns of uranopilite. The upper diffractogram was determined from the computed geometry and the lower one from the experimental one. ${ }^{2}$

and contains many reflections with intensities larger than $10 \%$. The largest variation in the computed positions is obtained for the $[-241]$ reflection $\left(2 \theta \sim 30.8^{\circ}\right)$, the difference being only about 0.8 degrees.

\subsection{Infrared spectroscopy}

The experimental infrared spectrum of uranopilite was acquired from a natural crystal specimen originating in Jáchymov (Czech Republic). The spectrum was also evaluated by employing first principles methods utilizing Density Functional Perturbation Theory (DFPT). Both spectra are displayed in Fig. 4 and as may be observed they are in very good accord. The bands in the experimentally determined spectrum are very wide and were resolved into single constituents (see Fig. S.4 of the ESI $\dagger$ ) employing the method depicted in a previous paper. ${ }^{18}$

The infrared spectrum of uranopilite samples from several different localities was measured in a previous work by Frost et al. ${ }^{84}$ The vibrational frequencies obtained in the present work are compared with those reported by Frost et al. ${ }^{84}$ in Table S.3 of the ESI. $\uparrow$ While the obtained frequencies are quite consistent, the results provided in this work are apparently more exhaustive and the rigorous assignment of the infrared bands afforded from the first principles calculation is quite different from the empirical assignment performed by Frost et al. ${ }^{84}$ In fact, the assignment by Frost et al. ${ }^{84}$ is very incomplete and the authors called the attention on the great difficulty of assigning many of the infrared bands due to its overlap with other bands. Furthermore, the existence of an overtone and a large number of combination bands (described in detail here) was not noticed by Frost et $a .^{84}$

The experimental and computed infrared band vibrational frequencies and the corresponding calculated intensities and assignments are given in Table S.4 of the ESI. $\dagger$ Additionally, Fig. S.5 (ESI $\dagger$ ) shows images of the vibrational atomic motions in a selection of the infrared active normal modes of uranopilite. The detailed analysis of the infrared spectrum was divided in five main 

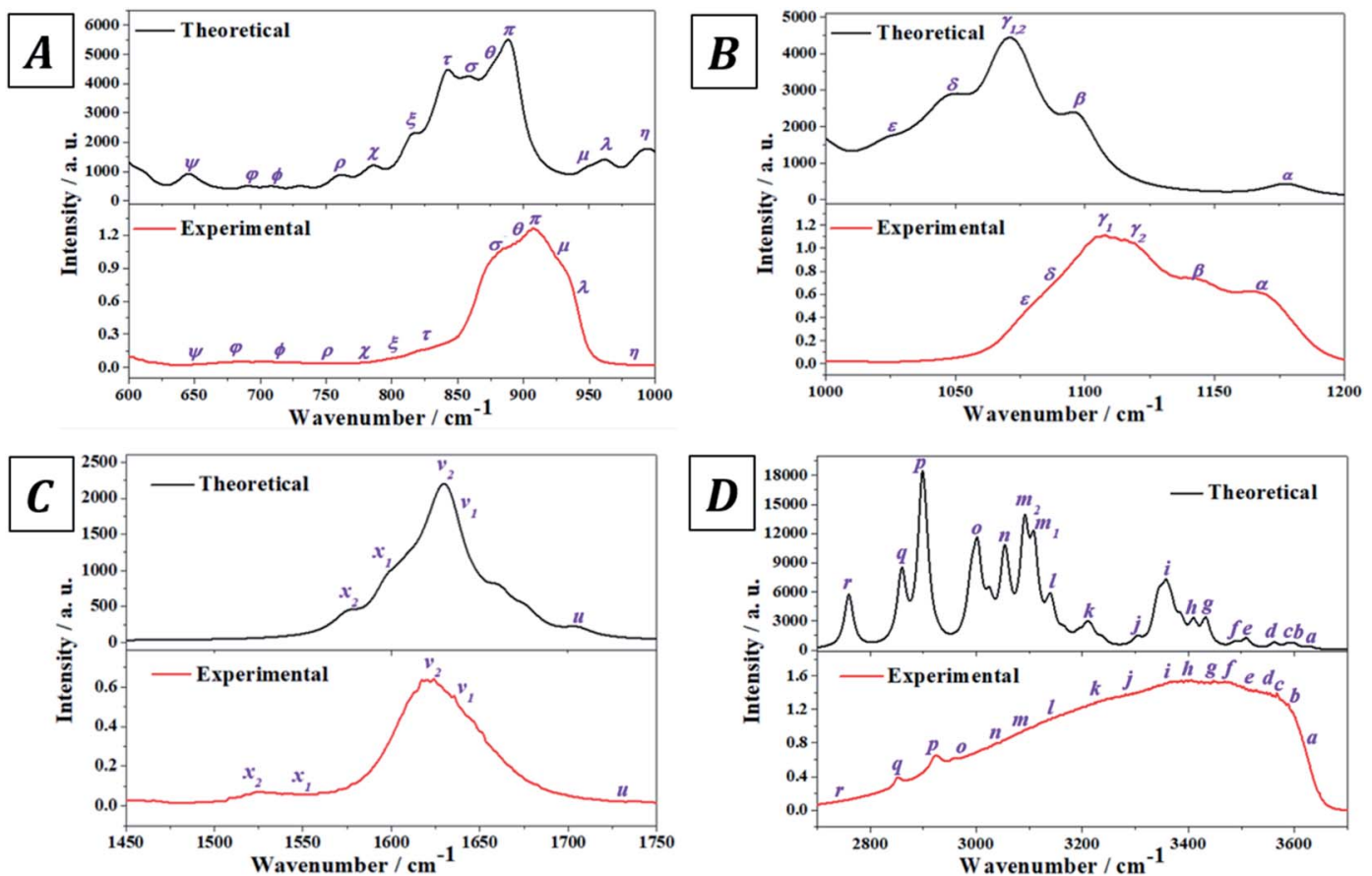

Fig. 4 Experimental and theoretical infrared spectra of uranopilite: (A) region $600-1000 \mathrm{~cm}^{-1}$; (B) region $1000-1200 \mathrm{~cm}^{-1}$; (C) region $1450-$ $1750 \mathrm{~cm}^{-1}$; (D) region $2700-3700 \mathrm{~cm}^{-1}$.

different spectral regions: (i) The region from 2200 to $3750 \mathrm{~cm}^{-1}$ (Fig. 4D, 5C and D); (ii) the region from 1300 to $1750 \mathrm{~cm}^{-1}$ (Fig. 4C and 5B); (iii) The region from 1000 to $1200 \mathrm{~cm}^{-1}$ (Fig. 4B and 5A); (iv) the region from 600 to $1000 \mathrm{~cm}^{-1}$ (Fig. 4A); and (v) the region from 400 to $600 \mathrm{~cm}^{-1}$. The last region, from 400 to $600 \mathrm{~cm}^{-1}$, is analyzed using the theoretical approach only. The study of the bands from this region is needed to identify the origin of some bands from the other spectral regions. The individual infrared bands pertaining to each spectral region are provided in separate sections of Table S.4. $\dagger$ The detailed analysis of the infrared spectrum of uranopilite and its assignment are given in Appendix B of the ESI. $\dagger$
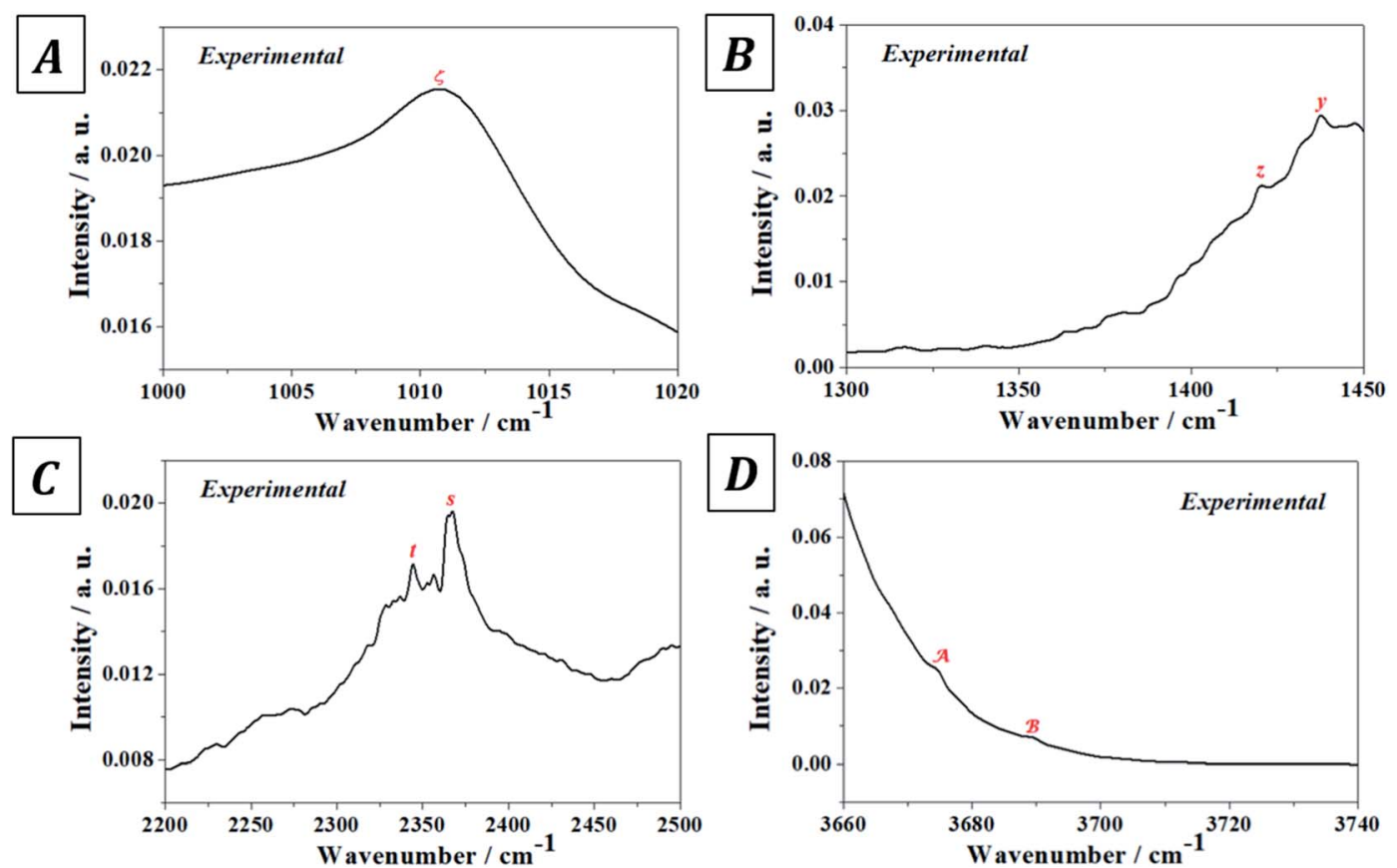

Fig. 5 Overtone and combination infrared bands in uranopilite: (A) region 1000-1020 cm ${ }^{-1}$; (B) region $1300-1350 \mathrm{~cm}^{-1}$; (C) region $2200-2500$ $\mathrm{cm}^{-1}$; (D) region $3660-3740 \mathrm{~cm}^{-1}$. 


\subsection{Mechanical properties}

2.5.1. Elasticity tensor and mechanical stability. The elasticity tensor of uranopilite was determined using the computed equilibrium crystal structure. Since uranopilite unit cell is triclinic, all elements in the matrix representation of the elasticity tensor are non-vanishing. ${ }^{85}$ The computed elasticity matrix is given in Table S.5 of the ESI. $\dagger$ As can be seen, the diagonal element of the elasticity matrix $C_{33}$ is nearly half the values of the other two diagonal elements. Clearly, this is a direct consequence of the layered structure of uranopilite. Layered materials are commonly weakly bound along the direction perpendicular to the layers and, as a result, the matrix element of the elasticity tensor along this direction is much smaller. From the computed elasticity matrix, the mechanical stability of uranopilite crystal structure was investigated. A given crystal structure is mechanically stable, if and only if, the associated elasticity matrix is positive definite (all its eigenvalues are positive). ${ }^{86}$ Therefore, the elasticity matrix of uranopilite was diagonalized numerically. All the eigenvalues were positive and, hence, uranopilite crystal structure is mechanically stable.

2.5.2. Mechanical properties. The elastic properties of polycrystalline aggregates of uranopilite were derived from the computed elasticity tensor employing the Voigt, ${ }^{\mathbf{8 7}}$ Reuss $^{\mathbf{8 8}}$ and Hill $^{89}$ approaches. The Voigt scheme was chosen to obtain the final mechanical properties of uranopilite because it yielded the best contrast of the computed bulk modulus with the single crystal bulk modulus extracted from the Birch-Murnaghan equation of state (EOS; see next Section). The mechanical properties obtained using the Voigt scheme are given in Table 3. The value obtained for the ductility index, $D=1.97$, is greater than 1.75 and, hence, uranopilite is a ductile mineral. ${ }^{90}$ Since the computed Vickers hardness is $H=0.61$, uranopilite is a material of low hardness. ${ }^{91}$ Uranopilite is very anisotropic mechanically because the calculated universal anisotropy index, ${ }^{92} A^{\mathrm{U}}=1.97$, is quite large.

Table 3 Calculated elastic properties of uranopilite using the Voigt approximation at $0 \mathrm{~K}$. The bulk, shear and Young moduli ( $B, G$ and $E$ ) values are expressed in GPa. The values of the bulk modulus and its first and second derivatives with respect to pressure obtained from the Birch-Murnaghan EOS are also given

\begin{tabular}{lll}
\hline & Property & Value \\
\hline$B$ & Bulk modulus & 21.52 \\
$G$ & Shear modulus & 10.94 \\
$E$ & Young modulus & 28.06 \\
$N$ & Poisson ratio & 0.28 \\
$D$ & Ductility index & 1.97 \\
$H$ & Hardness index & 0.67 \\
$A^{\mathrm{U}}$ & Universal anisotropy & 6.65
\end{tabular}

$\begin{array}{ll}\text { EOS } & \\ B & \text { Bulk modulus } \\ B^{\prime} & \text { Bulk modulus first derivative } \\ B^{\prime \prime} & \text { Bulk modulus second } \\ & \text { derivative }\end{array}$

$20.74 \pm 0.44$

$7.30 \pm 0.58$

$-2.21 \pm 0.50$
2.5.3. EOS and bulk modulus pressure derivatives. The crystal structure of uranopilite was fully optimized under the effect of seventeen different external hydrostatic pressures. The obtained unit cell volumes as a function of the external pressure are displayed in Fig. S.6 (ESI $\dagger$ ). The EOSFIT 5.2 software $^{93}$ was utilized to fit the pressure-volume data to a $4^{\text {th }}$ Birch-Murnaghan EOS: ${ }^{94}$

$$
\begin{aligned}
P= & 3 B f_{\mathrm{E}}\left(1+2 f_{\mathrm{E}}\right)^{\frac{5}{2}}\left[1+\frac{3}{2}\left(B^{\prime}-4\right) f_{\mathrm{E}}+\frac{3}{2}\left\{B B^{\prime \prime}\right.\right. \\
& \left.\left.+\left(B^{\prime}-4\right)\left(B^{\prime}-3\right) \frac{35}{9}\right\} f_{\mathrm{E}}^{2}\right]
\end{aligned}
$$

where:

$$
f_{\mathrm{E}}=\frac{1}{2}\left[\left(\frac{V_{0}}{V}\right)^{\frac{2}{3}}-1\right]
$$

The fitting parameters, $B, B^{\prime}$ and $\mathrm{B}^{\prime \prime}$ in eqn (1), are the bulk modulus and its first and second derivatives with respect to pressure. The values found are reported in Table 3 . The bulk moduli obtained from the EOS and from the computed elastic constants, $B=20.74 \pm 0.44 \mathrm{GPa}$ and $B=21.52 \pm 1.32 \mathrm{GPa}$, respectively, are in very good agreement.

2.5.4. Negative mechanical phenomena. The large mechanical anisotropy of uranopilite, reflected by large value of the universal anisotropy index, is explicitly displayed in Fig. 6 where the substantial dependence of the compressibility (the inverse of the bulk modulus), Young and shear moduli and Poisson's ratio on the direction of the applied strain is shown. Since large values of the mechanical anisotropy are strongly correlated with large values of the difference between the values of the minimum and maximum Poisson's ratios when all the possible orientations of the applied strain are considered, ${ }^{95}$ the elastic behavior of uranopilite was inspected to investigate the presence of negative mechanical properties. ${ }^{96-101}$ Fig. 6D shows that uranopilite displays negative values of the Poisson's ratio
A

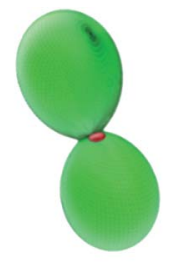

C

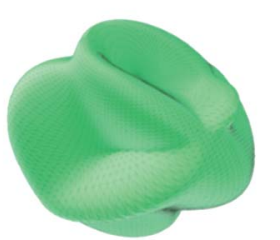

B

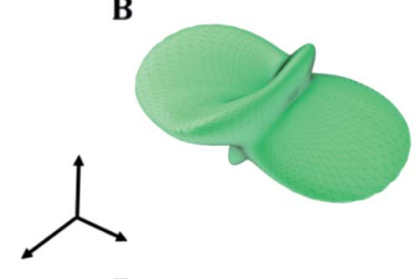

D

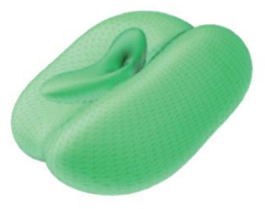

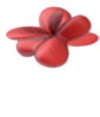

Fig. 6 Uranopilite elastic properties as a function of the direction of the applied strain: (A) compressibility (k); (B) Young modulus; (C) maximum shear modulus; (D) surfaces of maximum (green) and minimum (red) Poisson's ratio. The maximal values of the $k, E, G$ and $\nu$ are $67.86 \mathrm{TPa}^{-1}, 45.60 \mathrm{GPa}, 16.44 \mathrm{GPa}$ and 1.61, respectively. 

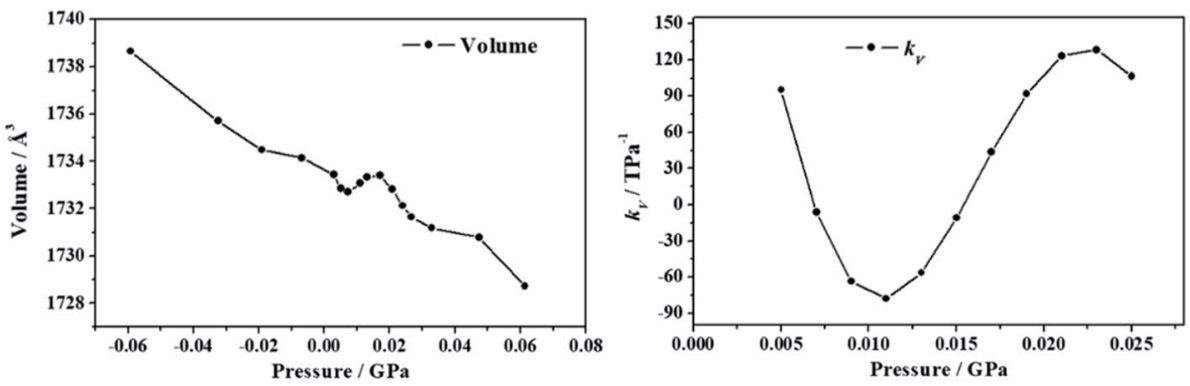

Fig. 7 Unit cell volumes and compressibilities $\left(k_{\mathrm{v}}\right)$ of uranopilite calculated as a function of the external pressure applied along the minimum compressibility direction.

(NPR phenomenon ${ }^{102,103}$ ). The minimum value of the Poisson's ratio, $\nu=-0.57$, found for an external pressure exerted along the longitudinal direction, $U_{\nu \text {-min }}^{L}=(0.53,0.80,0.30)$, is quite significant. Furthermore, uranopilite (see the red surface in Fig. 6D) also exhibits the negative linear compressibility (NLC) phenomenon. ${ }^{\mathbf{1 0 4 , 1 0 5}}$ The minimum compressibility is found for an external pressure applied along $U_{\mathrm{k}-\min }=(0.85,0.40,-0.34)$.

The underlying structural mechanism responsible for the NLC phenomenon in uranopilite and the precise values of the compressibility are studied in the next section by means of the analysis of the deformation of uranopilite crystal structure under pressure. It must be noticed that uranopilite shows a perfectly normal mechanical behavior under isotropic pressure. As shown in Fig. S.6 of the ESI, $\uparrow$ the volume and unit-cell parameters of uranopilite decrease under isotropic compression up to $5 \mathrm{GPa}$. The calculated values of the volumetric compressibility, $k_{\mathrm{V}}=-1 / V(\partial V / \partial P)_{P}$, in the pressure range from -0.5 to $4.0 \mathrm{GPa}$ are provided in Table S.6 and plotted in Fig. S.7. $\dagger$ The presence of negative compressibility under anisotropic pressure and its absence under hydrostatic pressure has been also observed recently for the zinc and cadmium oxalates. ${ }^{100}$

2.5.4.1. Deformation of the crystal structure under pressure. The crystal structure of uranopilite was optimized under the effect of thirteen different pressures directed along the minimum compressibility direction, $U_{k \text {-min }}$. The computed unit cell volumes are reported in Table S.7 $\uparrow$ and can be visualized in Fig. 7. The unit cell volume increases from $P=0.007 \mathrm{GPa}$ to $P=$ $0.015 \mathrm{GPa}$ and, therefore, the compressibility is negative in this pressure range. The computed values of the compressibility, $k_{\mathrm{V}}$ $=-1 / V(\partial V / \partial P)_{P}$, in the pressure range from $P=0.005$ to $P=$ $0.025 \mathrm{GPa}$ are provided in Table S. $8 \dagger$ and plotted in Fig. 7. The minimum value of the compressibility, $k_{\mathrm{v}}=-77.9 \mathrm{TPa}^{-1}$, is reached at $P=0.011 \mathrm{GPa}$.

In order to understand the structural variations leading to the NLC effect in uranopilite, the variation of the interatomic distances and angles and lattice parameters for the optimized structures corresponding to different pressures applied in the minimum compressibility direction were analyzed. The changes observed in the interatomic distances and angles within the uranium and sulfur coordination polyhedra and the hydrogen bond parameters were quite small. The largest structural variations occurring under the application of pressure were observed in the interlayer distance. The $c$ lattice parameter in uranopilite is exactly equal to two times the interlayer space. As can be seen in Table S.7, $\dagger$ from $P=$ $0.0029 \mathrm{GPa}$ to $P=0.0073 \mathrm{GPa}$, the unit cell volume decreases mainly due to the decrease of the $a$ and $c$ lattice parameters. However, from $P=0.0073 \mathrm{GPa}$ to $P=0.0131 \mathrm{GPa}$, while the $a$ lattice parameter decreases, the interlayer space (and the $c$ lattice parameter) increases leading to the increase of the total unit-cell volume. Therefore, the increase of the interlayer space is the main reason for the NLC effect in uranopilite. It is a physical effect related to the increase of the non-bonding distances along the [001] crystallographic direction under pressure.

The structure of uranopilite was also optimized for twelve different pressures directed along the minimum Poisson's ratio direction, $U_{\nu \text {-min }}^{\mathrm{L}}$. The resulting unit cell volumes are reported in Table S.9 $\uparrow$ and plotted in Fig. S. 8 of the ESI. $\dagger$ In this case, the unit cell volume increases from $P=0.014 \mathrm{GPa}$ to $P=0.024 \mathrm{GPa}$. Hence, negative values of the compressibility are present in this pressure range as can be observed in Fig. S.8. $\dagger$ The calculated values of compressibility from $P=0.003 \mathrm{GPa}$ to $P=0.029 \mathrm{GPa}$ are given in Table S.10. $\dagger$ The minimum value of the compressibility is $k_{\mathrm{V}}=-34.2 \mathrm{TPa}^{-1}$ and occurs at $P=$ $0.019 \mathrm{GPa}$. Therefore, uranopilite displays also significant negative compressibilities for external pressures applied along the direction of minimum Poisson's ratio. The variation of the geometric parameters under pressure was also analyzed and it was found that the increase of the interlayer space was, as in the case of pressures applied along the direction of minimum compressibility, the main responsible of the increase of volume.

\subsection{Thermodynamic properties}

2.6.1. Fundamental thermodynamic functions. The fundamental thermodynamic functions (ThF) of uranopilite were determined from the phonon spectra and phonon density of states resulting from first principles phonon calculations performed at the computed energy-optimized crystal structure. Fig. S.9 of the ESI $\dagger$ displays the resulting specific heat $\left(C_{\mathrm{p}}\right)$, entropy $(S)$, enthalpy $(H)$ and Gibbs free energy $(G)$ functions. Their values in the range of temperature extending from 0 to $1000 \mathrm{~K}$ are tabulated in of the ESI (Tables S.11-S.14). $\dagger$ The $H$ and $G$ functions given in these tables are provided in the same units as $C_{\mathrm{p}}$ and $S\left(\mathrm{~J} \mathrm{~K}^{-1} \mathrm{~mol}^{-1}\right)$ by dividing their values by the 
temperature. The ThFs of uranopilite, as far as we know, have never been measured even at room temperature. At $298.15 \mathrm{~K}$, the computed values of the specific heat and entropy are 179.6 and $209.0 \mathrm{~J} \mathrm{~K}^{-1} \mathrm{~mol}^{-1}$, respectively. The value of $C_{\mathrm{p}}$ at the upper limit of the temperature range studied $(1000 \mathrm{~K})$ is $271.94 \mathrm{~J} \mathrm{~K}^{-1}$ $\mathrm{mol}^{-1}$, which is still $17.2 \%$ lower than the asymptotic limit dictated by the law of Dulong and Petit $\left(328.41 \mathrm{~J} \mathrm{~K}^{-1} \mathrm{~mol}^{-1}\right)$.

2.6.2. Thermodynamic functions of formation. The value of the enthalpy of formation of uranopilite in terms of the elements at the standard state has not been measured experimentally. For this reason, an estimate of $\Delta_{\mathrm{f}} H^{0}$ was obtained by employing the method of Tardy and Garrels, ${ }^{\mathbf{1 0 6}}$ as developed specifically for uranyl-containing compounds by Finch $^{\mathbf{1 0 7}}$ and Ewing and coworkers. ${ }^{\mathbf{1 0 8 , 1 0 9}}$ The value obtained was $\Delta_{\mathrm{f}} H^{0}=$ $-2163.8 \pm 10 \mathrm{~kJ} \mathrm{~mol}^{-1}\left(\Delta_{\mathrm{f}} G^{0}=-1905.4 \pm 10 \mathrm{~kJ} \mathrm{~mol}^{-1}\right)$, where the error was determined approximately from the differences between the measured and estimated values in a series of compounds in which the corresponding experimental $\Delta_{\mathrm{f}} H^{0}$ is known. The enthalpies of formation (EnOF) and Gibbs free energies of formation (GiFEOF) of uranopilite in terms of the elements as a function of temperature were obtained from its computed fundamental ThFs, the estimated value of $\Delta_{\mathrm{f}} H^{0}$ and

Table 4 Computed temperature dependent enthalpy $\left(\Delta_{\mathrm{f}} H\right)$ and Gibbs free energy $\left(\Delta_{\mathrm{f}} G\right)$ functions of formation of uranopilite. The values of $\Delta_{\mathrm{f}} \mathrm{H}$ and $\Delta_{\mathrm{f}} G$ are given in units of $\mathrm{kJ} \mathrm{mol}^{-1}$

\begin{tabular}{lllr}
\hline$T(\mathrm{~K})$ & $\Delta_{\mathrm{f}} H$ & $\Delta_{\mathrm{f}} G$ & $\log K$ \\
\hline 298.15 & -2163.76 & -1905.40 & 333.81 \\
300 & -2163.03 & -1903.02 & 331.34 \\
350 & -2146.80 & -1842.35 & 274.95 \\
400 & -2135.74 & -1787.25 & 233.39 \\
450 & -2128.41 & -1736.25 & 201.53 \\
500 & -2123.91 & -1688.40 & 176.38 \\
550 & -2121.64 & -1643.04 & 156.04 \\
600 & -2121.17 & -1599.71 & 139.26 \\
650 & -2122.19 & -1558.05 & 125.20 \\
700 & -2124.46 & -1517.82 & 113.26 \\
750 & -2127.81 & -1478.79 & 102.99 \\
800 & -2132.09 & -1440.81 & 94.07
\end{tabular}

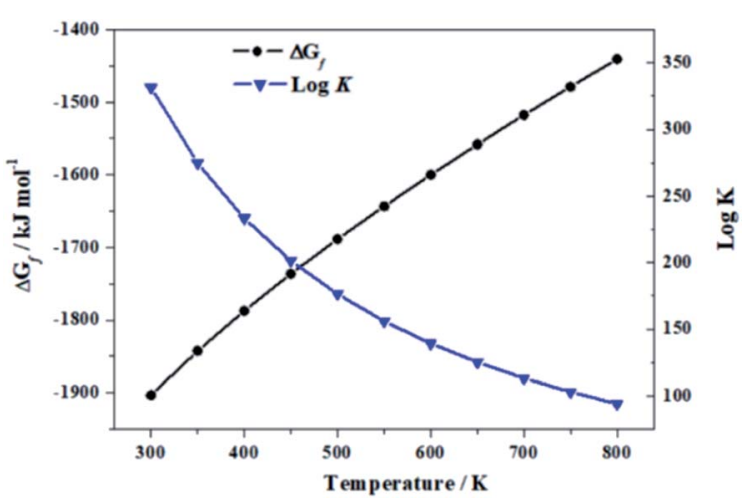

Fig. 8 Calculated GiFEOF of uranopilite in terms of the elements as a function of temperature and corresponding reaction constants. the experimental ThFs of the elements $\mathrm{H}, \mathrm{O}$ and $\mathrm{S}$ taken form Joint Army-Navy-Air Force (JANAF) thermochemical tables ${ }^{\mathbf{1 1 0}}$ and those of $U$ from Barin. ${ }^{111}$ The results are reported in Table 4 and plotted in Fig. 8. Since, according to eqn (A1) and (A2) of Appendix A, $\uparrow$ the contribution of $\Delta_{\mathrm{f}} H^{0}$ to the EnOF and GiFEOF at a certain temperature is additive, if the value of $\Delta_{\mathrm{f}} H^{0}$ of uranopilite is accurately measured hereafter, the temperature dependent thermodynamic functions of formation (ThFOF) could be easily re-evaluated by subtracting the estimated $\Delta_{\mathrm{f}} H^{0}$ from the values provided in Table 4 and adding the value obtained experimentally.

2.6.3. Thermodynamic functions of reaction. The enthalpies and Gibbs free energies of reaction (EnOR and GiFEOR) and the associated reaction constants for the reactions of transformation of uranopilite into gamma uranium trioxide $\left(\gamma\right.$-UO $\left.\mathrm{U}_{3}\right)$, dehydrated schoepite $\left(\mathrm{UO}_{2}(\mathrm{OH})_{2}\right)$, rutherfordine $\left(\mathrm{UO}_{2} \mathrm{CO}_{3}\right)$ and soddyite $\left(\left(\mathrm{UO}_{2}\right)_{2}\left(\mathrm{SiO}_{4}\right) \cdot 2 \mathrm{H}_{2} \mathrm{O}\right)$ :

$$
\begin{aligned}
& \mathrm{UO}_{3}(\mathrm{cr})+1 / 6 \mathrm{SO}_{3}(\mathrm{~g})+17 / 6 \mathrm{H}_{2} \mathrm{O}(\mathrm{l}) \rightarrow 1 / 6\left(\mathrm{UO}_{2}\right)_{6}\left(\mathrm{SO}_{4}\right) \\
& \mathrm{O}_{2}(\mathrm{OH})_{6} \cdot 14 \mathrm{H}_{2} \mathrm{O}(\mathrm{cr}) \\
& \mathrm{UO}_{3} \cdot \mathrm{H}_{2} \mathrm{O}(\mathrm{cr})+1 / 6 \mathrm{SO}_{3}(\mathrm{~g})+11 / 6 \mathrm{H}_{2} \mathrm{O}(\mathrm{l}) \rightarrow 1 / 6\left(\mathrm{UO}_{2}\right)_{6}\left(\mathrm{SO}_{4}\right) \\
& \mathrm{O}_{2}(\mathrm{OH})_{6} \cdot 14 \mathrm{H}_{2} \mathrm{O}(\mathrm{cr}) \\
& \mathrm{UO}_{2} \mathrm{CO}_{3}(\mathrm{cr})+1 / 6 \mathrm{SO}_{3}(\mathrm{~g})+17 / 6 \mathrm{H}_{2} \mathrm{O}(\mathrm{l}) \rightarrow 1 / 6\left(\mathrm{UO}_{2}\right)_{6}\left(\mathrm{SO}_{4}\right) \\
& \mathrm{O}_{2}(\mathrm{OH})_{6} \cdot 14 \mathrm{H}_{2} \mathrm{O}(\mathrm{cr})+\mathrm{CO}_{2}(\mathrm{~g}) \\
& 1 / 2\left(\mathrm{UO}_{2}\right)_{2}\left(\mathrm{SiO}_{4}\right) \cdot 2 \mathrm{H}_{2} \mathrm{O}(\mathrm{cr})+1 / 6 \mathrm{SO}_{3}(\mathrm{~g})+11 / 6 \mathrm{H}_{2} \mathrm{O}(\mathrm{l}) \rightarrow 1 / \\
& 6\left(\mathrm{UO}_{2}\right)_{6}\left(\mathrm{SO}_{4}\right) \mathrm{O}_{2}(\mathrm{OH})_{6} \cdot 14 \mathrm{H}_{2} \mathrm{O}(\mathrm{cr})+1 / 2 \mathrm{SiO}_{2}(\mathrm{cr})
\end{aligned}
$$

were obtained by merging the calculated ThFOFs of uranopilite with those determined for these materials previously. ${ }^{67}$ The experimental ThFOFs of the materials entering in these reactions which do not contain the uranyl ion were obtained from the JANAF thermochemical tables. ${ }^{110}$ The thermodynamic functions of reaction (ThFOR) obtained are given in Table S.14 of the ESI $\dagger$ and plotted in Fig. 9. Fig. 9A shows that uranopilite becomes unstable with respect to the uranium and sulfur trioxides at $110{ }^{\circ} \mathrm{C}(383 \mathrm{~K})$. Similarly, Fig. 9B shows that dehydrated schoepite will transform into uranopilite in the presence of sulfur trioxide for temperatures larger than $83{ }^{\circ} \mathrm{C}(356 \mathrm{~K})$. From Fig. 9C, it follows that uranopilite will convert into rutherfordine in the presence of carbon dioxide for the full range of temperature considered (300 to $500 \mathrm{~K}$ ). Likewise (Fig. 9D), uranopilite is predicted to transform into soddyite under the presence of silicon dioxide from 300 to $500 \mathrm{~K}$. Since the free energy of the reaction (D) is larger than that of (C), under the simultaneous presence of $\mathrm{CO}_{2}$ and $\mathrm{SiO}_{2}$, uranopilite will convert into soddyite.

2.6.3.1. The presence of hydrogen peroxide. The ThFORs of the reactions of conversion of uranopilite into schoepite, $\left[\left(\mathrm{UO}_{2}\right)_{8} \mathrm{O}_{2}(\mathrm{OH})_{12}\right] \cdot 12 \mathrm{H}_{2} \mathrm{O}$, and studtite, $\left(\mathrm{UO}_{2}\right) \mathrm{O}_{2} \cdot 4 \mathrm{H}_{2} \mathrm{O}$ :

$$
\begin{aligned}
& 1 / 6\left(\mathrm{UO}_{2}\right)_{6}\left(\mathrm{SO}_{4}\right) \mathrm{O}_{2}(\mathrm{OH})_{6} \cdot 14 \mathrm{H}_{2} \mathrm{O}(\mathrm{cr})+7 / 48 \mathrm{O}_{2} \rightarrow \\
& 1 / 8\left[\left(\mathrm{UO}_{2}\right)_{8} \mathrm{O}_{2}(\mathrm{OH})_{12}\right] \cdot 12 \mathrm{H}_{2} \mathrm{O}(\mathrm{cr})+1 / 6 \mathrm{SO}_{3}(\mathrm{~g}) \\
& +7 / 24 \mathrm{H}_{2} \mathrm{O}(\mathrm{l})+7 / 24 \mathrm{H}_{2} \mathrm{O}_{2}(\mathrm{l})
\end{aligned}
$$



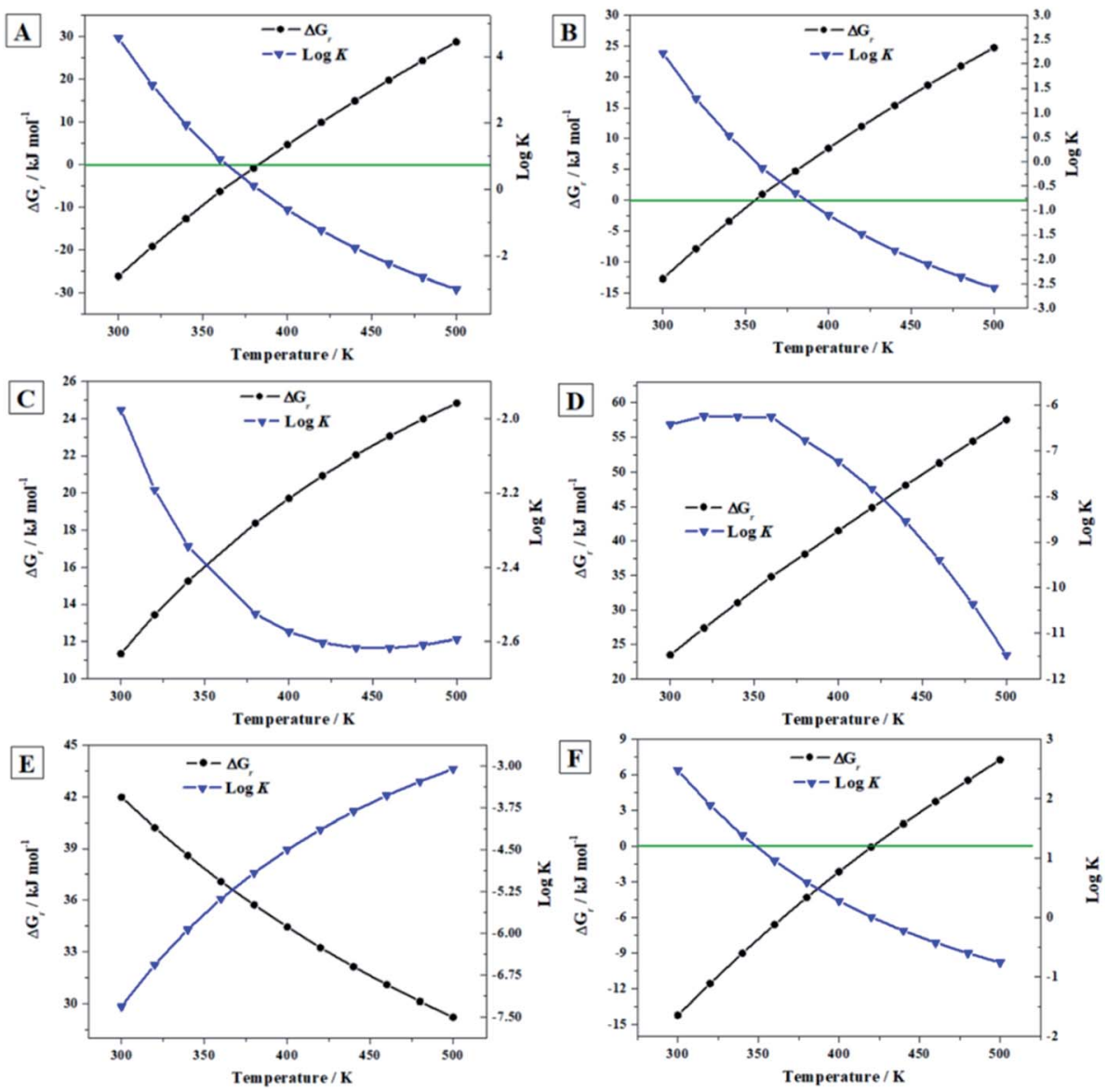

Fig. 9 Computed Gibbs free energies of reaction and corresponding reaction constants for the reactions (A) to (F) as a function of temperature.

$1 / 6\left(\mathrm{UO}_{2}\right)_{6}\left(\mathrm{SO}_{4}\right) \mathrm{O}_{2}(\mathrm{OH})_{6} \cdot 14 \mathrm{H}_{2} \mathrm{O}(\mathrm{cr})+7 / 6 \mathrm{H}_{2} \mathrm{O}_{2}(\mathrm{l}) \rightarrow$

$\left(\mathrm{UO}_{2}\right) \mathrm{O}_{2} \cdot 4 \mathrm{H}_{2} \mathrm{O}(\mathrm{cr})+1 / 6 \mathrm{SO}_{3}(\mathrm{~g})+1 / 12 \mathrm{O}_{2}(\mathrm{~g})$

were obtained by merging the calculated ThFOFs of uranopilite and those of schoepite ${ }^{16}$ and studtite. ${ }^{67}$ The transformation of uranopilite into schoepite in reaction (E) occurs under the presence of equal amounts of $\mathrm{H}_{2} \mathrm{O}$ and $\mathrm{H}_{2} \mathrm{O}_{2}$. Uranopilite converts into studtite in the presence of $\mathrm{H}_{2} \mathrm{O}_{2}$ and absence of $\mathrm{H}_{2} \mathrm{O}$ in reaction (F). The presence of $\mathrm{H}_{2} \mathrm{O}_{2}$ and absence of $\mathrm{H}_{2} \mathrm{O}$ in the reaction $(\mathrm{F})$ is a very important condition because it must be encountered under intense radiation fields leading to the radiolysis of majority of the $\mathrm{H}_{2} \mathrm{O}$ reaching the surface of SNF. ${ }^{112-114}$ The required ThFOFs of $\mathrm{O}_{2}, \mathrm{SO}_{3}$ and $\mathrm{H}_{2} \mathrm{O}$ were acquired from Chase et al. ${ }^{110}$ and those of $\mathrm{H}_{2} \mathrm{O}_{2}$ were taken from Barin. ${ }^{111}$ The results are given in Table S.15† and shown in Fig. 9. Since the Gibbs free energy of reaction (E) is positive at all the temperatures considered (Fig. 9E), uranopilite is very stable under the simultaneous presence of $\mathrm{H}_{2} \mathrm{O}$ and $\mathrm{H}_{2} \mathrm{O}_{2}$ and should not transform into schoepite. Conversely, schoepite should convert into uranopilite under these conditions in the presence of sulfur trioxide. Under the presence of $\mathrm{H}_{2} \mathrm{O}_{2}$ and absence of $\mathrm{H}_{2} \mathrm{O}$ (Fig. 9F), uranopilite should transform into studtite only up to $148{ }^{\circ} \mathrm{C}(421 \mathrm{~K})$.
2.6.4. Uranopilite relative thermodynamic stability with respect to other secondary phases of SNF. By using the ThFs of uranopilite reported in the present paper and the ThFs reported in previous works, ${ }^{16,17,20,21,67,68}$ the relative ThS of twelve important secondary phases of SNF (dehydrated schoepite, studtite, metastudtite, soddyite, rutherfordine, schoepite, metaschoepite, becquerelite, vandenbrandeite, uranosphaerite, uranopilite and $\gamma$ - $\mathrm{UO}_{3}$ ) was evaluated: (A) under $\mathrm{H}_{2} \mathrm{O}_{2}$-free conditions; (B) in the simultaneous presence of $\mathrm{H}_{2} \mathrm{O}$ and $\mathrm{H}_{2} \mathrm{O}_{2}$; and (C) under high concentration of $\mathrm{H}_{2} \mathrm{O}_{2}$. The resulting ThS are displayed in Fig. 10A, B and C, respectively, in the temperature range going from 300 to $500 \mathrm{~K}$. In these figures, the ThSs are measured with respect to $\gamma-\mathrm{UO}_{3}$, metastudite and studtite, respectively.

Under $\mathrm{H}_{2} \mathrm{O}_{2}$-free conditions (Fig. 10A), the most stable phase from 300 to $500 \mathrm{~K}$ is the uranyl silicate soddyite. At $300 \mathrm{~K}$, uranopilite is the fourth more stable mineral phase after soddyite, rutherfordine and becquerelite. Hence, uranopilite should be replaced by other phases in the absence of $\mathrm{H}_{2} \mathrm{O}_{2}$ and in the presence of, for instance, silicate or carbonate ions. However (Fig. 10B), uranopilite is highly stabilized under the presence of $\mathrm{H}_{2} \mathrm{O}$ and $\mathrm{H}_{2} \mathrm{O}_{2}$ and becomes the most stable phase among those studied in this paper. Lastly, as shown in Fig. 10C, under high concentration of $\mathrm{H}_{2} \mathrm{O}_{2}$, the uranyl peroxide hydrate 

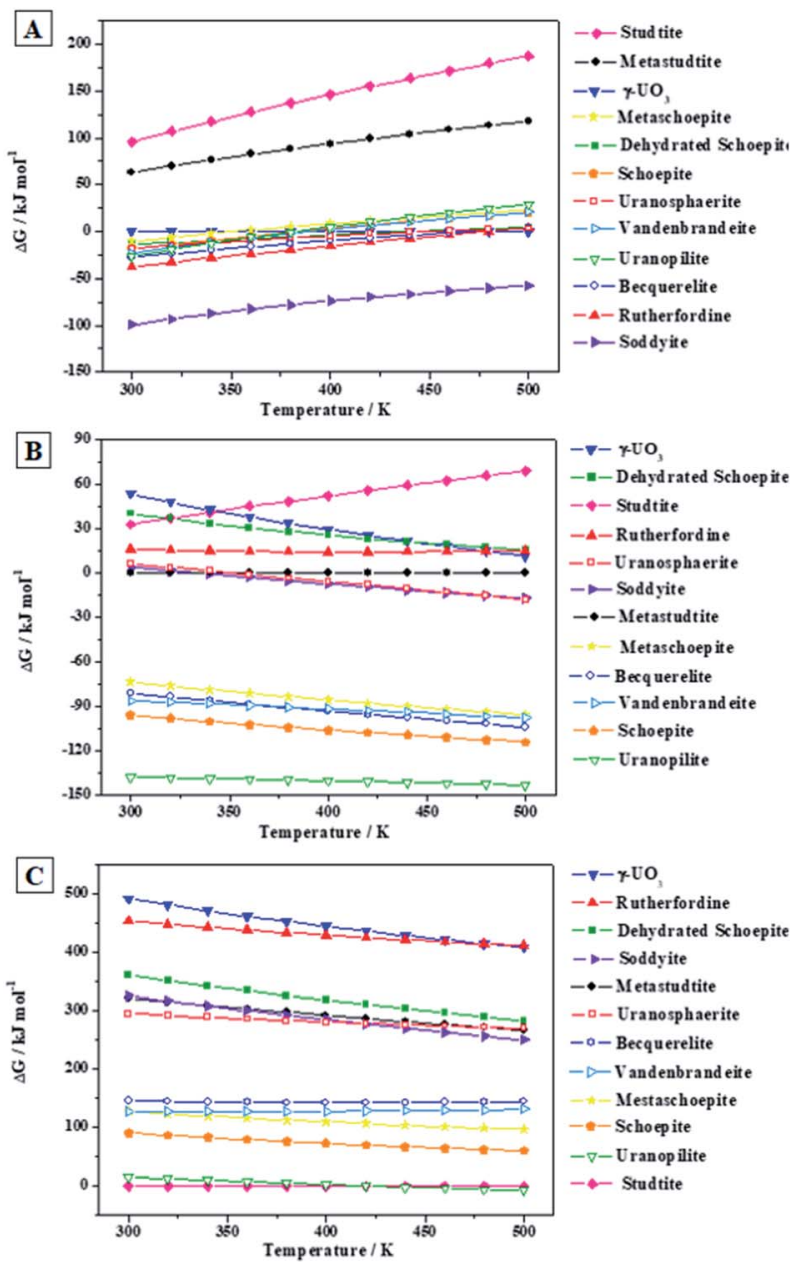

Fig. 10 Relative ThS of uranopilite with respect to other secondary phases of SNF at different conditions: (A) under $\mathrm{H}_{2} \mathrm{O}_{2}$-free conditions; (B) under the presence of $\mathrm{H}_{2} \mathrm{O}$ and $\mathrm{H}_{2} \mathrm{O}_{2} ;$; (C) under high concentration of $\mathrm{H}_{2} \mathrm{O}_{2}$. The labels of the phases considered are arranged vertically according to their relative ThS at the temperature of $300 \mathrm{~K}$.

phase studtite is the most stable one in line with the results obtained in previous papers ${ }^{16,17,20,21,67,68}$ and uranopilite becomes the second most stable secondary phase of SNF among those considered in the present paper. However, this is true only for temperatures lower than $148{ }^{\circ} \mathrm{C}(421 \mathrm{~K})$, and for larger temperatures uranopilite is more stable than studtite. Due to the importance of these results, the precise experimental measurement of the standard state enthalpy of formation of uranopilite in terms of the elements appears to be required to reduce the uncertainty in the estimate used here. Although at temperatures higher than $148{ }^{\circ} \mathrm{C}$, it may be thought that some degree of dehydration of uranopilite may occur, it should be emphasized that the present results refer to the condition of presence of $\mathrm{H}_{2} \mathrm{O}_{2}$ and absence of $\mathrm{H}_{2} \mathrm{O}$. Under this condition, the most hydrated phases appear to be more stable than the corresponding phases appearing due to its dehydration at $\mathrm{H}_{2} \mathrm{O}_{2}$ free conditions. For example, as showed in Fig. 10E, studtite is more stable than metastudtite from 300 to $500 \mathrm{~K}^{68}$ and the same occurs for schoepite and metaschoepite. ${ }^{17}$ Furthermore, mineral metauranopilite is highly dubious ${ }^{8,77}$ and no one report on the existence of this phase has been published since $1941 .^{75,76}$ Theoretical computations aimed to find this phase have also being unsuccessful so far. The thermal decomposition curve of uranopilite, reported in Appendix C of the ESI $\dagger$ does not support the existence of this phase due to the monotonous dehydration thermogravimetric (TG) curve.

\section{Conclusions}

The complete crystal structure of mineral uranopilite was determined using first principles solid-state methods based on DFT. Since the calculated structural information and X-ray powder diffraction pattern were in excellent agreement with the experimental information, the hydrogen bonding network resulting from the computed positions of the hydrogen atom must be reliable. The infrared spectrum of uranopilite was collected from a natural crystal sample from Jáchymov (Czech Republic) and computed using DFPT. The good agreement between both spectra provided additional support for the computed structure. The high degree of consistency between both spectra allowed for the assignment of all the bands in the experimental spectrum to specific vibrational atomic motions. The proposed assignment is very different to the one performed previously ${ }^{84}$ using empirical arguments. Besides, one infrared band was recognized as an overtone and six additional bands were identified as combination bands.

The access of the energy-optimized crystal structure facilitated the determination of the elasticity matrix and phonon spectra of uranopilite employing the first principles methodology. From the calculated elasticity matrix, the mechanical stability of the crystal structure of uranopilite was stablished and an abundant set of elastic properties were determined. Uranopilite was found to have a large mechanical anisotropy and to exhibit the negative Poisson's ratio and negative linear compressibility phenomena. The mechanism responsible for the negative linear compressibility effect of uranopilite under the effect of external pressures applied along the direction of minimum compressibility was investigated by analyzing the deformation of the crystal structures under pressure. The anomalous expansion of the interlayer space was found to be the main cause of the increase of the unit cell volume of uranopilite under the effect of compressive pressure. The minimum value of the compressibility was found to be $k_{\mathrm{V}}=$ $-77.9 \mathrm{TPa}^{-1}$, for an applied external pressure of $0.011 \mathrm{GPa}$.

The fundamental thermodynamic functions of uranopilite, unknown so far, were obtained from the computed phonon spectra as a function of the temperature. These thermodynamic functions were used to determine the thermodynamic functions of formation of uranopilite in terms of the elements and the thermodynamic functions of reaction for a set of reactions relating uranopilite and a subgroup of the most prominent secondary phases of spent nuclear fuel. The thermodynamic reaction data was used in order to obtain the relative thermodynamic stability of uranopilite with respect to these phases as a function of temperature and under different concentrations of hydrogen peroxide. The results show that uranopilite is highly 
stable under the presence of hydrogen peroxide and becomes the most stable phase under the simultaneous presence of water and hydrogen peroxide. Besides, under the presence of hydrogen peroxide and absence of water, uranopilite is the second most stable phase after studtite at low temperatures and become the most stable phase at $148{ }^{\circ} \mathrm{C}$. The high stability of uranopilite under these conditions explains its early crystallization in the paragenetic sequence of secondary phases occurring when natural uraninite is exposed to low-pH sulfur-rich solutions. From the point of view of nuclear waste disposal, sulfur-free conditions should be insured in a repository to avoid the possible formation of uranyl sulfate minerals. With the attenuation of the intensity of the strong radiation fields associated to the SNF over time, the concentration of hydrogen peroxide should decrease significantly and these minerals should dissolve into water forming very mobile uranyl sulfate complexes.

\section{Conflicts of interest}

There are no conflicts of interest to declare.

\section{Acknowledgements}

The computation time provided by the Centro Técnico de Informática from CSIC is deeply acknowledged. This work has been performed in the framework of a CSIC-CIEMAT collaboration agreement: "Caracterización experimental y teórica de fases secundarias y óxidos de uranio formados en condiciones de almacenamiento de combustible nuclear". We thank Jana Ederová (Institute of Chemical Technology in Prague, Czech Republic) for the carefully undertaken thermal analysis. JP acknowledges the support of the Czech Science Foundation through the project GACR 20-11949S. VT is grateful for the financial support of the Ministry of Science, Innovation and Universities of Spain through Project FIS2016-77726-C3-1-P. JČ acknowledge the financial support of the Ministry of Culture of the Czech Republic (long-term project DKRVO 2019-2023/1.II.b; National Museum, 00023272).

\section{References}

1 C. Frondel, Am. Mineral., 1952, 37, 950-959.

2 P. C. Burns, Can. Mineral., 2001, 39, 1139-1146.

3 J. Plášil, J. Sejkora, P. Škácha, V. Goliaš and M. Hušák, Bull. Mineral. Petrol., 2005, 13, 192-196.

4 J. Sejkora, J. Litochleb, B. Bureš and J. Jindra, Bull. Mineral. Petrol., 2004, 12, 171-174.

5 N. Meisser, Beitr. Geol. Schweiz, Geotech. Ser., 2012, 96, 1183.

6 J. Plášil, J. Sejkora, R. Škoda and P. Škácha, J. Geosci., 2014, 59, 223-253.

7 R. J. Finch and T. Murakami, Rev. Mineral. Geochem., 1999, 38, 91-179.

8 S. V. Krivovichev and J. Plášil, in Uranium: From Cradle to Grave, ed. P. C. Burns and G. E. Sigmon, Mineralogical
Association of Canada, Winnipeg, MB, Canada, 2013, Short Course 43, pp. 15-119.

9 J. Plášil, J. Geosci., 2014, 59, 99-114.

10 R. J. Baker, Coord. Chem. Rev., 2014, 266-267, 123-136.

11 A. J. Lussier, R. A. K. Lopez and P. C. Burns, Can. Mineral., 2016, 54, 177-283.

12 V. V. Gurzhiy and J. Plášil, Acta Crystallogr., Sect. B: Struct. Sci., Cryst. Eng. Mater., 2019, 75, 39-48.

13 H. Dauber, Ann. Phys., 1854, 92, 237-251.

14 A. Weisbach, Neu. Jb. Geol. Paläont, 1882, 2, 249-259.

15 F. Colmenero, J. Cobos and V. Timón, Inorg. Chem., 2018, 57, 4470-4481.

16 F. Colmenero, A. M. Fernández, J. Cobos and V. Timón, ACS Earth Space Chem., 2019, 3, 17-28.

17 F. Colmenero, A. M. Fernández, V. Timón and J. Cobos, RSC Adv., 2018, 8, 24599-24616.

18 F. Colmenero, J. Plášil, J. Cobos, J. Sejkora, V. Timón, J. Čejka and L. J. Bonales, RSC Adv., 2019, 9, 15323-15334.

19 F. Colmenero, J. Plášil and J. Sejkora, Dalton Trans., 2019, 48, 16722-16736.

20 F. Colmenero, J. Plášil, J. Cobos, J. Sejkora, V. Timón, J. Čejka, A. M. Fernández and V. Petř́iček, RSC Adv., 2019, 9, 40708-40726.

21 F. Colmenero, J. Plášil and I. Němec, J. Phys. Chem. Solids, 2020, 141, 109400.

22 F. Colmenero, J. Plášil and P. Škácha, Spectrochim. Acta, Part A, 2020, 234, 118216.

23 D. K. Nordstrom and C. N. Alpers, in Reviews in Economic Geology, ed. G. S. Plumlee and M. J. Logsdon, Society of Economic Geologists, Littleton, CO, 1999, ch. 6, vol. 6A, pp. 133-160.

24 K. J. Edwards, P. L. Bond, G. K. Druschel, M. M. Mcguire, R. J. Hamers and J. F. Banfield, Chem. Geol., 2000, 169, 383-397.

25 Z. Bian, X. Miao, S. Lei, S. Chen, W. Wang and S. Struthers, Science, 2002, 37, 702-703.

26 H. E. Jamieson, S. R. Walke and M. B. Parsons, Appl. Geochem., 2015, 57, 85-105.

27 I. Grenthe, J. Fuger, R. J. M. Konings, R. J. Lemire, A. B. Muller, C. Nguyen-Trung, H. Wanner, Chemical Thermodynamics of Uranium, Nuclear Energy Agency Organisation for Economic Co-Operation and Development, OECD, Issy-les-Moulineaux, France, 2004.

28 N. Y. R. Guillaumont, T. Fanghänel, V. Neck, J. Fuger, D. A. Palmer, I. Grenthe and M. H. Rand, Update on the Chemical Thermodynamics of Uranium, Neptunium, Plutonium, Americium, and Technetium, ed. F. J. Mompean, M. Illemassene, C. Domenech-Orti and K. Ben Said, OECD Nuclear Energy Agency, Data Bank, Issy-lesMoulineaux, France, 2003.

29 S. A. Cumberland, G. Douglas, K. Grice and J. W. Moreau, Earth-Sci. Rev., 2016, 159, 160-185.

30 D. Langmuir, Geochim. Cosmochim. Acta, 1978, 42, 547-569.

31 D. Langmuir, Aqueous Environmental Geochemistry, Prentice-Hall, New York, 1997; pp. 486-557.

32 C. Nguyen-Trung, G. M. Begun and D. A. Palmer, Inorg. Chem., 1992, 3, 5280-5287. 
33 A. Gianguzza, D. Milea, F. J. Millero and S. Sammartano, Mar. Chem., 2004, 85, 103-124.

34 V. Vallet, I. Grenthe, C. R. Chimie, 2007, 10, 905-915.

35 C. Hennig, K. Schmeide, V. Brendler, H. Moll, S. Tsushima and A. C. Scheinost, Inorg. Chem., 2007, 46, 5882-5892.

36 C. Hennig, S. Tsushima, V. Brendler, A. Ikeda, A. C. Scheinost and G. Bernhard, in Uranium, Mining and Hydrogeology, ed. B. J. Merkel and A. Hasche-Berger, Springer, Berlin, 2008; pp. 603-614.

37 D. Vopálka, K. Štamberg, A. Motl and B. Drtinová, J. Radioanal. Nucl. Chem., 2010, 286, 681-686.

38 L. Rao, G. Tian, Y. Xia, J. I. Friese, P. Zanonato and P. Di Bernardo, in Nuclear Energy and the Environment, American Chemical Society, Washington DC, 2010.

39 S. Berto, F. Crea, P. G. Daniele, A. Gianguzza, A. Pettignano and S. Sammartano, Coord. Chem. Rev., 2012, 256, 63-81.

40 A. Kalintsev, A. Migdisov, H. Xu, R. Roback and J. Brugger, Geochim. Cosmochim. Acta, 2019, 267, 75-91.

41 H. M. Fernandes, L. H. S. Veiga, M. R. Franklin, V. C. S. Prado and J. F. Taddei, J. Geochem. Explor., 1996, 52, 161-173.

42 J. Brugger and P. C. Burns, N. Meisser, Am. Mineral., 2003, 88, 676-685.

43 K. Maher, J. R. Bargar and G. E. Brown, Inorg. Chem., 2013, 52, 3510-3532.

44 B. Novotnik, W. Chen and R. D. Evans, Appl. Geochem., 2018, 91, 36-44.

45 D. D. Runnells, T. A. Sheperd and E. E. Angino, Environ. Sci. Technol., 1992, 26, 2316-2323.

46 K. D. Kelley and C. D. Taylor, Appl. Geochem., 1997, 12, 397409.

47 R. A. Zielinski, W. H. Orem, K. R. Simmons and P. J. Bohlen, Water, Air, Soil Pollut., 2006, 176, 163-183.

48 C. G. Warren, Econ. Geol., 1972, 67, 759-767.

49 R. L. Reynolds and M. B. Goldhaber, Econ. Geol., 1983, 78, 105-120.

50 A. Bhattacharyya, K. M. Campbell, S. D. Kelly, Y. Roebbert, S. Weyer, R. Bernier-Latmani and T. Borch, Nat. Commun., 2007, 8, 15538.

51 J. A. Plant, P. R. Simpson, B. Smith and B. F. Windley, Rev. Mineral. Geochem., 1999, 38, 255-319.

52 R. J. Finch and R. C. Ewing, Uraninite Alteration in an Oxidizing Environment and its Relevance to the Disposal of Spent Nuclear Fuel, SKB Technical Report 91-15, Swedish Nuclear Fuel and Waste Management Co, Stockholm, Sweden, 1994.

53 R. S. Forsyth and L. O. Werme, J. Nucl. Mater., 1992, 90, 319.

54 E. C. Pearcy, J. D. Prikryl, W. M. Murphy and B. W. Leslie, Appl. Geochem., 1994, 9, 713-732.

55 D. J. Wronkiewicz, J. K. Bates, T. J. Gerding, E. Veleckis and B. S. Tani, J. Nucl. Mater., 1992, 190, 107-127.

56 D. J. Wronkiewicz, J. K. Bates, S. F. Wolf and E. C. Buck, J. Nucl. Mater., 1996, 238, 78-95.

57 J. Bruno, I. Casas, E. Cera, R. C. Ewing, R. J. Finch and L. O. Werme, Mater. Res. Soc. Symp. Proc., 1994, 353, 633639.
58 J. Bruno and R. C. Ewing, Elements, 2006, 2, 343-349.

59 R. C. Ewing, Nat. Mater., 2015, 14, 252-255.

60 Modelling in Aquatic Chemistry, ed. I. Grenthe and I. Puigdomenech, OECD Nuclear Energy Agency Data Bank, OECD/NEA, Stockholm. 1997.

61 C. J. Chisholm-Brause, J. M. Berg, K. M. Little, R. A. Matzner and D. E. Morr, J. Colloid Interface Sci., 2004, 277, 366-382.

62 T. Behrends, E. Krawczyk-Bärsch and T. Arnold, Appl. Geochem., 2013, 27, 453-462.

63 C. Tournassat and C. I. Steefel, Rev. Mineral. Geochem., 2019, 85, 75-109.

64 V. Lagneau, O. Regnault and M. Descostes, Rev. Mineral. Geochem., 2019, 85, 499-528.

65 O. Bildstein, F. Claret and P. Frugier, Rev. Mineral. Geochem., 2019, 85, 419-457.

66 F. Endrizzi, X. Gaona, M. Marques-Fernandes, B. Baeyens and M. Altmaier, J. Chem. Thermodyn., 2018, 120, 45-53.

67 F. Colmenero, A. M. Fernández, J. Cobos and V. Timón, J. Phys. Chem. C, 2018, 122, 5254-5267.

68 F. Colmenero, A. M. Fernández, J. Cobos and V. Timón, J. Phys. Chem. C, 2018, 122, 5268-5279.

69 NEA Data Bank, , Thermochemical Database (TDB), accessed 15 April, , 2020, https://www.oecd-nea.org/dbtdb/.

70 , Thermo-Chimie database (Consortium Andra-Ondraf/ Niras-RWM), accessed 15 April, , 2020, http:// www.thermochimie-tdb.com/.

71 M. Sharifironizi, J. E. S. Szymanowski, G. E. Sigmon, A. Navrotsky, J. B. Fein and P. C. Burns, Chem. Geol., 2016, 447, 54-58.

72 M. Sharifironizi and P. C. Burns, Can. Mineral., 2018, 56, 714.

73 D. Gorman-Lewis, P. C. Burns and J. B. Fein, J. Chem. Thermodyn., 2008, 40, 335-352.

74 P. Wersin, M. F. Hochella, P. Persson, G. Redden, J. O. Leckie and D. W. Harris, Geochim. Cosmochim. Acta, 1998, 58, 2829-2843.

75 R. Nováček, Věstník Královské České Společnosti Nauk, 1935, vol. 7, pp. 1-36.

76 R. Nováček, Věstník Královské České Společnosti Nauk, Třida matematicko-př́rodovědná, 1941, pp. 1-15.

77 P. Ondruš, F. Veselovský, J. Hlousek, R. Skála, J. Vavřín, J. Frýda, J. Čejka and A. Gabašová, J. Czech Geol. Soc., 1959, 42, 3-76.

78 J. Čejka, J. Sejkora, Z. Mrázek, Z. Urbanec and T. Jarchovsky, Neues Jahrbuch Mineral. Abhand., 1996, 170, 155-170.

79 G. Lu, A. Haes and T. Z. Forbes, Coord. Chem. Rev., 2018, 374, 314-344.

80 R. J. P. Driscoll, D. Wolverson, J. M. Mitchels, J. M. Skelton, S. C. Parker, M. Molinari, I. Khan, D. Geeson and G. C. Allen, RSC Adv., 2014, 4, 59137-59149.

81 P. F. Weck, E. Kim, C. F. Jové-Colón and D. C. Sassani, Dalton Trans., 2013, 42, 4570-4578.

82 P. C. Burns, R. C. Ewing and F. C. Hawthorne, Can. Mineral., 1997, 35, 1551-1570.

83 MaterialsStudio, 15 April, , 2020, http://3dsbiovia.com/ products/collaborative-science/biovia-materials-studio/. 
84 R. L. Frost, J. Čejka, M. L. Weier, W. N. Martens and G. A. Ayoko, J. Raman Spectrosc., 2007, 38, 398-409.

85 P. F. Weck, E. Kim and E. C. Buck, RSC Adv., 2015, 5, 7909079097.

86 F. Mouhat and F. X. Coudert, Phys. Rev. B, 2014, 90, 224104.

87 W. Voigt, Lehrbuch der Kristallphysik, Teubner, Leipzig, 1962.

88 A. Reuss, Z. Angew. Math. Mech., 1929, 9, 49-58.

89 R. Hill, Proc. Phys. Soc., London, Sect. A, 1952, 65, 349-354.

90 S. F. Pugh, Philos. Mag., 1954, 45, 823-843.

91 H. Niu, P. Wei, Y. Sun, C. X. Chen, C. Franchini, D. Li and Y. Li, Appl. Phys. Lett., 2011, 99, 031901.

92 S. I. Ranganathan and M. Ostoja-Starzewski, Phys. Rev. Lett., 2008, 101, 055504.

93 EOSFIT 5.2 software, http://programming.ccp14.ac.uk/ccp/ web-mirrors/ross-angel/crystal/software.html, accessed 15 April, 2020.

94 F. Birch, Phys. Rev., 1947, 71, 809-824.

95 Z. A. D. Lethbridge, R. I. Walton, A. S. H. Marmier, C. W. Smith and K. E. Evans, Acta Mater., 2010, 58, 64446451.

96 F. Colmenero, J. Cobos and V. Timón, J. Phys.: Condens. Matter, 2019, 31, 175701.

97 F. Colmenero, Mater. Res. Express, 2019, 6, 045610.

98 F. Colmenero, Phys. Chem. Chem. Phys., 2019, 21, 26732690.

99 F. Colmenero, Adv. Theory Simul., 2019, 2, 1900040.

100 F. Colmenero and V. Timón, J. Mater. Sci., 2020, 55, 218236.
101 F. Colmenero, J. Sejkora and J. Plášil, Sci. Rep., 2020, 10, 7510.

102 R. S. Lakes, Science, 1987, 235, 1038-1040.

103 R. S. Lakes, Annu. Rev. Mater. Res., 2017, 47, 63-81.

104 R. H. Baughman, S. Stafström, C. Cui and S. O. Dantas, Science, 1998, 279, 1522-1524.

105 A. B. Cairns and A. L. Goodwin, Phys. Chem. Chem. Phys., 2000, 17, 20449-20465.

106 Y. Tardy and R. M. Garrels, Geochim. Cosmochim. Acta, 1976, 41, 1051-1056.

107 R. J. Finch, Mater. Res. Soc. Symp. Proc., 1997, 465, 11851192.

108 S. B. Clark, R. C. Ewing and J. C. Schaumloffel, J. Alloys Compd., 1998, 271-273, 189-193.

109 F. Chen, R. C. Ewing and S. B. Clark, Am. Mineral., 1999, 84, 650-664.

110 M. W. Chase, C. A. Davies, J. R. Downey, D. J. Frurip, R. A. McDonald and A. N. Syverud, J. Phys. Chem. Ref. Data, 1985, 14(Suppl. 1), 1-1856.

111 I. Barin, Thermochemical Data of Pure Substances, VCH, Weinheim, Third edn, 1995.

112 E. Ekeroth, O. Roth and M. Jonsson, J. Nucl. Mater., 2006, 355, 38-46.

113 A. Barreiro-Fidalgo, Y. Kumagai and M. Jonsson, J. Coord. Chem., 2018, 71, 1799-1807.

114 A. C. Maier, P. Kegler, M. Klinkenberg, A. Baena, S. Finkeldei, F. Brandt and M. Jonsson, Dalton Trans., 2020, 49, 1241-1248. 